\title{
Effect of Several Enzyme Solutions on the Isolation and Culture of Grape Mesophyll Protoplasts
}

\author{
Thawansak Phosang ${ }^{1,2}$, Nagao Matsuta ${ }^{1}$, Hiroyuki Iketani ${ }^{1}$, Tateki Hayashi ${ }^{1}$ \\ and Ryosuke Ogata ${ }^{2}$ \\ ${ }^{1}$ Fruit Tree Research Station, Tsukuba, Ibaraki 305 \\ ${ }^{2}$ Faculty of Agriculture, Utsunomiya University, Utsunomiya, Tochigi 321
}

\begin{abstract}
Summary
Viable mesophyll protoplasts were isolated from in vitro grown leaves of grapes (Vitis labruscana cv. Kyoho and $V$. vinifera cv. Cabernet Sauvignon). The best yield of mesophyll protoplasts $\left(1.8 \times 10^{7}\right.$ and $2.4 \times 10^{7} \cdot \mathrm{g}^{-1}$ leaf fresh weight, 'Kyoho' and 'Cabernet Sauvignon', respectively) was obtained in a combined enzyme solution of $0.5 \%$ Cellulase YC, $0.2 \%$ Macerozyme R-10 and $0.1 \%$ Driselase. More than $85 \%$ of the isolated protoplasts were viable. Most protoplasts regenerated the cell wall within first 5 days of culture. Cell division occurred after 5 to 10 days of culture in Gamborg's B5 liquid medium supplemented with $5 \mu \mathrm{M} 2.4-\mathrm{D}, 2.5 \mu \mathrm{M}$ BA and $0.6 \mathrm{M}$ sorbitol. In 'Kyoho', $12 \%$ of cell division frequency was found in the protoplasts isolated with $0.5 \%$ Cellulase YC, $0.2 \%$ Macerozyme R-10, $0.1 \%$ Driselase and $0.01 \%$ Pectolyase Y-23. In 'Cabernet Sauvignon', the frequency of cell division was low (1.4\%) when the same enzyme solution was used for the protoplast isolation.
\end{abstract}

\section{Introduction}

Tetraploid grapes are attractive because of their bigger berries. These have been produced by crossing between tetraploid cultivars or chromosome doubling by the colchicine treatment. However, recent progress of biotechnology has been contribut. ing to the development of new methods for genetic improvement of cultivars. A somatic hybrid produced by cell fusion between diploid cultivars is tetraploid, having both parent genomes. As no segregation of genomes occurs in the case of cell fusion, a tetraploid produced by cell fusion has a different genotype from the progeny of a cross hybridization even if the diploid parents are the same. Furthermore, the induction of somaclonal variation during cell and tissue culture, which may change one or more characteristics, is also expected in the plants regenerated from protoplasts. These techniques result in expanding the available materials for cultivar improvement. Thus, the establishment of protoplast culture system has a

Received for publication 19 January 1994. significant value to advancing grape breeding.

Many trials of the protoplast isolation and culture in Vitis spp. have been reported (Skene, 1975; Shimizu, 1985; Wright, 1985; Lee and Wetzstein, 1988; Barbier and Bessis, 1990; Marino, 1990; Theodoropoulos and Roubelakis-Angelakis, 1990; Mii et al., 1991; Katsirdakis and Roubelakis-Angelakis, 1992). However, callus formation from mesophyll protoplasts is still difficult except for one success (Lee and Wetzstein, 1988); plant regeneration has not yet been achieved. Many factors in protoplast isolation and culture are involved in callus formation from iso. lated protoplasts. Shimizu (1985) reported that the addition of Pectolyase $\mathrm{Y}-23$ to the enzyme solution was effective for increasing protoplast yield. Pectolyase $\mathrm{Y}-23$ decreased protoplast cell division unless the concentration was reduced to $0.01 \%$. Lee and Wetzstein (1988) reported that higher enzyme concentration released more protoplasts than did the lower one. The higher enzyme concentration decreased protoplast viability. Thus, enzymes used for protoplast isolation influence release and subsequent division of isolated proto- 
plasts.

The present paper reports the effect of the enzyme composition on the mesophyll protoplast isolation and culture in 2 grape cultivars; V. labruscana cv. Kyoho and $V$. vinifera cv. Cabernet Sauvignon.

\section{Materials and Methods}

Shoot tip cultures of grapes (Vitis labruscana cv. Kyoho and $V$. vinifera cv. Cabernet Sauvignon) were established by nodal culture. Nodal segments, excised from plants grown in a greenhouse, were cultured on MS (Murashige and Skoog, 1962) medium supplemented with $2.5 \mu \mathrm{M}$ BA and $0.1 \mu$ $M$ NAA. Shoots were subcultured monthly on the same medium. To induce roots, elongated shoots were imbedded in MS medium supplemented with $0.2 \mu \mathrm{M}$ NAA. Rooted plants were transferred to a hormone-free MS medium for further growth. All cultures were maintained at $25{ }^{\circ} \mathrm{C}$ in a $16 \mathrm{hr}$ photoperiod (about 3000 lux).

Two or three fully expanded leaves of the upper part of in vitro plants were used for protoplast isolation. Leaf tissues, without mid-rib $(0.1 \sim 0.2$ $\mathrm{g})$, were cut into small segments and immersed in $10 \mathrm{ml}$ of a filter-sterilized enzyme solution. Enzyme solutions, used in the experiments, are listed in Table 1. In the first experiment, enzyme solutions $\mathrm{A}$ to $\mathrm{D}$ were used to determine the cellulase most suitable for protoplast isolation from grape leaf tissues. In the second experiment, enzyme solutions $D$ to $G$ were used to examine the effect of the enzyme composition on the protoplast isolation and culture. The mixtures were allowed to stand for 5 minutes under reduced pressure and incubated at $25{ }^{\circ} \mathrm{C}$ for $4,6,8$ and 10 hours without shaking. After enzyme digestion, the mixtures were filtered through a $37 \mu \mathrm{m}$ nylon mesh. The filtrate was centrifuged at $50 \times \mathrm{g}$ for 3 minutes and the supernatant was removed. The protoplast pellet was resuspended in a washing solution of $0.6 \mathrm{M}$ sorbitol. $10 \mathrm{mM} \mathrm{CaCl} 2 \cdot \mathrm{H}_{2} \mathrm{O}$ and $1 \mathrm{mM}$ $\mathrm{KH}_{2} \mathrm{PO}_{4}$ at $\mathrm{pH} 5.8$ and recentrifuged at $50 \times \mathrm{g}$. This procedure was repeated thrice. The washed protoplasts were resuspended in a filter-sterilized liquid culture medium at $2 \times 10^{5} \cdot \mathrm{ml}^{-1}$ density. The culture medium consisted of B5 basal medium at $\mathrm{pH} 5.8$ (Gamborg et al., 1968) supplemented with $5 \mu \mathrm{M} \mathrm{2,4-D,} 2.5 \mu \mathrm{M}$ BA and $0.6 \mathrm{M}$ sorbitol. A $1.5 \mathrm{ml}$ aliquot of protoplast suspension was transferred to a Petri dish ( $35 \mathrm{~mm}$ diameter) and cultured at $25^{\circ} \mathrm{C}$ in the dark.

Protoplast yield was calculated with a hemacytometer. The viability of protoplasts was assessed at $0,5,10$ and 15 days after culture by staining them with fluorescein diacetate. The cell wall regeneration was checked at 5,10 and 15 days after culture by staining the protoplasts with Calcofluor White. All the experiments were repeated thrice.

\section{Results and Discussion}

In this experiment, leaves of in vitro rooted plants grown on a hormone-free medium were used because the physiological condition of leaves significantly affects the efficiency of protoplast isola tion and its culture. The effectiveness of in vitro leaves of grape for the protoplast isolation, compared with the leaves grown in a greenhouse or field was reported as for yield, viability or stability (Barbier and Bessis, 1988; Theodoropoulos and Roubelakis-Angelakis, 1990). Reported plants grown on a hormone-free medium supplies physiologically uniform leaves compared with those from shoot tip culture; the former are not influenced by phytohormones in the medium.

The effect of cellulase solutions A, B, C and D (Table 1) gave varied protoplast yields after a 10 hour incubation (Table 2). Among 4 cellulases examined, Cellulase YC (enzyme solution D) gave the highest yield, followed by Cellulase RS (enzyme solution B) for both cultivars. The viability of isolated protoplasts was more than $90 \%$ regardless of the cellulase; however, results indicate that Cellulase $\mathrm{YC}$ is the most suitable cellulase.

The tests of different enzyme solutions D, E, F and $G$ (Table 1 ) on protoplast isolation yielded results for 'Kyoho' (Fig. 1). Of the 5 enzyme solutions, solution $\mathrm{F}$ after a 10 -hour incubation gave the highest yield of $1.8 \times 10^{7}$ protoplasts $\cdot \mathrm{g}^{-1}$ leaf fresh weight (Fig. 2). The leaf, treated with enzyme solution $E$ lacking in Driselase, had the lowest yield. The addition of Driselase promoted the protoplast isolation. Solution G, obtained by adding Pectolyase $Y-23$ to solution $F$, did not increase protoplast yield compared to solution $\mathrm{F}$, indicating that the addition of Pectolyase $Y-23$ was not always effective for protoplast isolation. More than $85 \%$ of the protoplast isolated with any enzyme solution was viable; the enzyme solutions containing Driselase decreased the viability of pro. 
Table 1. Composition of enzyme solutions used for protoplast isolation from grape leaf.

\begin{tabular}{|c|c|c|c|c|c|c|c|}
\hline & \multicolumn{7}{|c|}{ Enzyme solution } \\
\hline & A & B & C & $\mathrm{D}$ & $\mathrm{E}$ & $\mathrm{F}$ & $G$ \\
\hline Cellulase $\mathrm{R}-10^{2}(\% \mathrm{w} / \mathrm{v})$ & 1.0 & & & & & & \\
\hline Cellulase $\operatorname{RS}^{2}(\% \mathrm{w} / \mathrm{v})$ & & 1.0 & & & & & \\
\hline MeicelaseP- $1^{y}(\% \mathrm{w} / \mathrm{v})$ & & & 1.0 & & & & \\
\hline Cellulase $\mathrm{YC}^{\mathrm{x}}(\% \mathrm{w} / \mathrm{v})$ & & & & 1.0 & 0.5 & 0.5 & 0.5 \\
\hline Macerozyme $\mathrm{R}-10^{\mathrm{z}}(\% \mathrm{w} / \mathrm{v})$ & 0.5 & 0.5 & 0.5 & 0.5 & 0.2 & 0.2 & 0.2 \\
\hline Driselase $^{w}(\% \mathrm{w} / \mathrm{v})$ & & & & & & 0.1 & 0.1 \\
\hline Pectolyase $Y-23^{x}(\% w / v)$ & & & & & & . & 0.01 \\
\hline $\operatorname{MES}(\mathrm{mM})$ & 10 & 10 & 10 & 10 & 10 & 10 & 10 \\
\hline DTT (mM) & 1 & 1 & 1 & 1 & 1 & 1 & 1 \\
\hline Sorbitol (M) & 0.6 & 0.6 & 0.6 & 0.6 & 0.6 & 0.6 & 0.6 \\
\hline $\mathrm{pH}$ & 5.7 & 5.7 & 5.7 & 5.7 & 5.7 & 5.7 & 5.7 \\
\hline \multicolumn{8}{|c|}{$z$ Yakult Pharmaceutical Co. Ltd. } \\
\hline \multicolumn{8}{|c|}{$\begin{array}{ll}\text { y } & \text { Meiji Seika Co. Ltd. } \\
x & \text { Seishin Pharmaceutical Co. Ltd. }\end{array}$} \\
\hline
\end{tabular}

Table 2. Effect of cellulase type on yield and viability of protoplasts isolated from grape leaf tissue.

\begin{tabular}{crcrrr}
\hline \hline \multirow{2}{*}{$\begin{array}{c}\text { Enzyme } \\
\text { solution }\end{array}$} & \multicolumn{2}{c}{ Kyoho } & & \multicolumn{2}{c}{ Cabernet Sauvignon } \\
\cline { 2 - 3 } \cline { 5 - 6 } & Yield $^{2}$ & Viability $^{y}$ & & Yield $^{z}$ & Viability $^{y}$ \\
\hline $\mathrm{A}$ & $1.3 \mathrm{c}^{\mathrm{x}}$ & $90.4 \mathrm{~b}$ & & $3.8 \mathrm{c}$ & $92.7 \mathrm{~b}$ \\
$\mathrm{~B}$ & $10.0 \mathrm{~b}$ & $91.9 \mathrm{ab}$ & $13.3 \mathrm{~b}$ & $94.6 \mathrm{a}$ \\
$\mathrm{C}$ & $3.5 \mathrm{c}$ & $90.6 \mathrm{~b}$ & $5.1 \mathrm{c}$ & $93.3 \mathrm{ab}$ \\
$\mathrm{D}$ & $16.8 \mathrm{a}$ & $94.0 \mathrm{a}$ & $16.5 \mathrm{a}$ & $94.9 \mathrm{a}$ \\
\hline
\end{tabular}

$z$ Yield $\left(\times 10^{6} \cdot \mathrm{g}^{-1}\right.$ leaf fresh weight $)$.

v Viability (\%).

$x$ Treatment means separated in columns by Duncan's Mul tiple Test. $5 \%$.

toplasts. In 'Cabernet Sauvignon' cells, solution F was effective, yielding $2.5 \times 10^{7}$ protoplasts $\cdot \mathrm{g}^{-1}$ leaf fresh weight. This enzyme solution on the protoplast isolation of 'Cabernet Sauvignon' was similar to that for 'Kyoho' (data not shown). These results suggest that the enzyme solution $F$ was most suitable of the 5 enzyme solutions in terms of yield and viability, which are comparable to the other reports (Shimizu, 1985; Lee and Wetzstein, 1988; Barbier and Bessis, 1990; Marino, 1990; Theodoropoulos and Roubelakis-Angelakis, 1990), although the isolation procedures and the cultivars were different.

The viability and the cell wall regeneration were observed in the protoplast isolated by incubation for 8 or 10 hours in each enzyme solu-

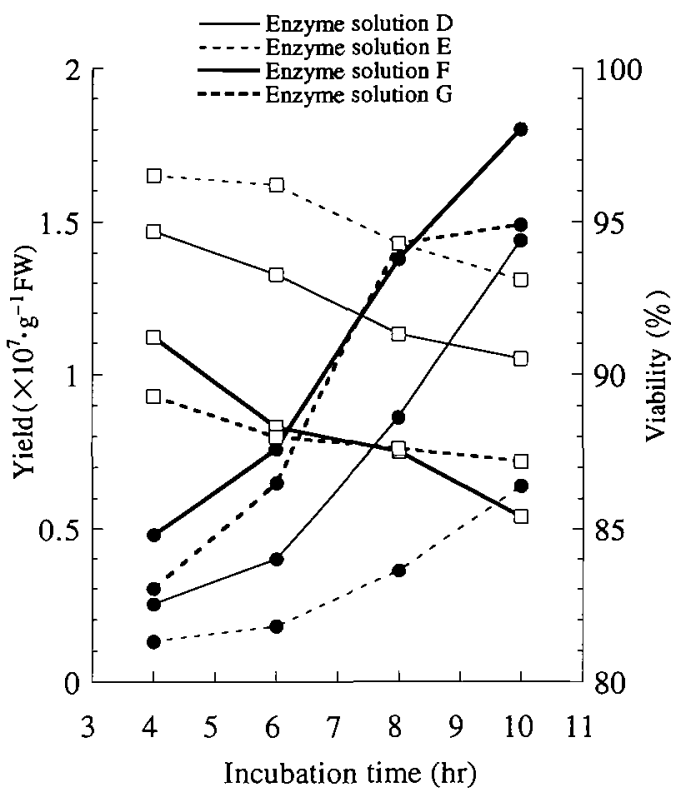

Fig. 1. Time course of yield and viability of isolated protoplasts from 'Kyoho' leaves with each enzyme solution. Symbols : - - ; yield, $-\square$-; viability.

tion. The results obtained in 'Kyoho' are shown in Fig. 3. More than $60 \%$ of protoplasts isolated with any enzyme solution regenerated the cell walls within 5 days of culture. In the protoplasts isolated with the solution E, $79 \%$ of the protoplasts regenerated cell wall 15 days after culture. The 


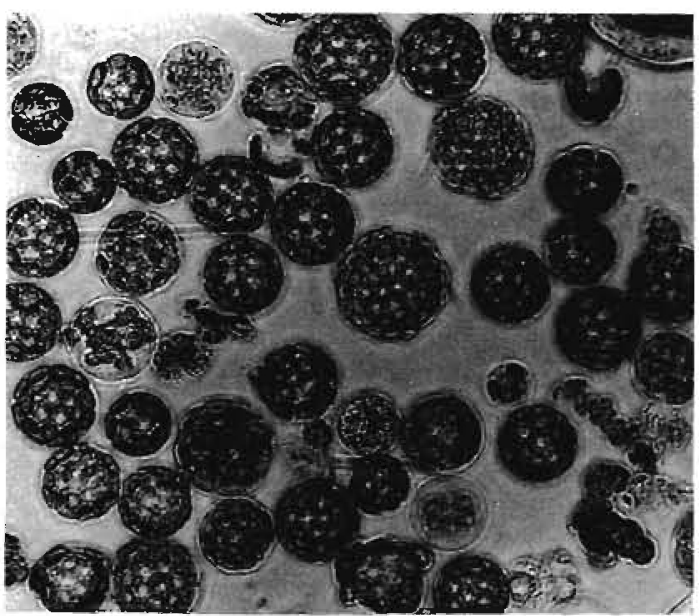

Fig. 2. Photomicrograph of protoplasts isolated from 'Kyoho' leaves.

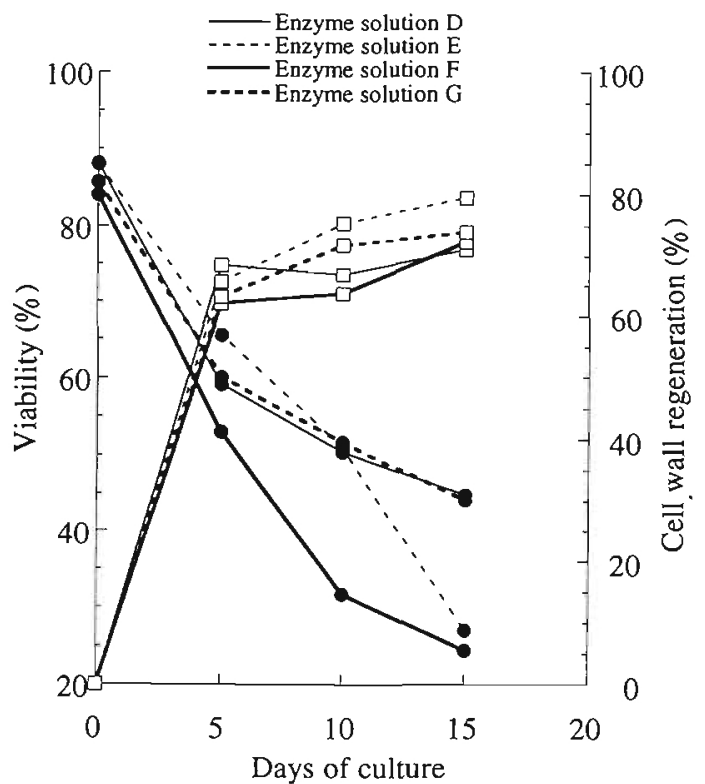

Fig. 3. Time course of viability and cell wall regenera. tion during culture in 'Kyoho' protoplasts isolated with each enzyme solution. Symbols : - - ; viabil. ity, $-\square$-; cell wall regeneration.

viability of protoplasts isolated with any enzyme solution decreased to less than $40 \% 15$ days after culture. In 'Cabernet Sauvignon', the effect of the enzyme solution on protoplast culture was similar to that of 'Kyoho' (data not shown). The cell wall regeneration rate of protoplasts, isolated with solution $\mathrm{E}$ was $50 \% 5$ days after culture and increased to a maximum of $74 \%$ after 15 days in culture. These rates are less than those for 'Kyoho'.

Cell division was also affected markedly by the enzyme solution (Table 3). In 'Kyoho', the first cell division occurred in the protoplasts, isolated with solution $G 5$ days after culture. The protoplasts, isolated with other enzyme solutions, did not start to divide. After 15 days of culture, about $12 \%$ of protoplasts, isolated with solution G showed cell division (Fig. 4). Cell division frequency in 'Cabernet Sauvignon' was low. The enzyme solution $G$ also gave the best result, but only $1.4 \%$ of the isolated protoplasts divided. This experiment showed that isolating protoplasts with en zyme solution $G$ was the most suitable for both

Table 3. Effect of enzyme composition on cell division of protoplasts isolated from grape leaf tissue.

\begin{tabular}{ccc}
\hline \hline \multirow{2}{*}{$\begin{array}{c}\text { Enzyme } \\
\text { solution }\end{array}$} & \multicolumn{2}{c}{ Cell division $(\%)^{x}$} \\
\cline { 2 - 3 } & Kyoho & Cabernet Sauvignon \\
\hline D & - & $0.6 \mathrm{a}$ \\
E & $1.2 \mathrm{~b}^{\mathrm{x}}$ & $0.7 \mathrm{a}$ \\
$\mathrm{F}$ & - & $1.4 \mathrm{a}$ \\
$\mathrm{G}$ & $11.9 \mathrm{a}$ & \\
\hline
\end{tabular}

2 Measurement was conducted after 15 days of isolated protoplast culture.

* Cell division was not observed.

* Treatment means separated in columns by Duncan's Multiple Test. $5 \%$.

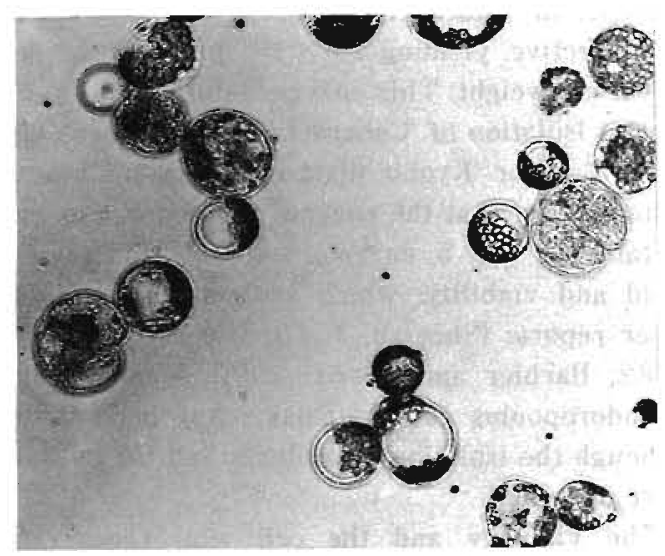

Fig. 4. Photomicrograph of dividing protoplasts derived from "Kyoho' mesophyll tissue. 
cultivars. A second cell division occurred in some cases. However, all divided protoplasts turned brown in further culture, and no colony formation was obtained in either cultivar.

There are many reports on somatic embryogenesis in grapes (Hirabayashi, 1985; Stamp and Meredith, 1988; Matsuta and Hirabayashi, 1989; Marchenko, 1991; Matsuta 1992; Martinelli et al., 1993; Robacker, 1993) or adventitious shoot formation (Clog et al., 1990) via callus induced from the leaf tissues. If callus formation is achievable from the mesophyll protoplasts (Lee and Wetzstein, 1988), it seems possible to regenerate plants, although testing factors such as protoplast density and liquid vs. solid medium have not clarified what inhibits further growth of divided protoplasts.

The present study was carried out to determine suitable enzyme solutions for protoplast isolation and culture. After the most suitable enzyme solu. tion is found, improving the culture of protoplasts will be the next step. Further study in this area is now under way.

\section{Literature Cited}

Barbier, M. and R. Bessis. 1988. Effects de différents facteurs contribuant à l'amélioration de l'isolement de protoplastes à partir de feuilles de vigne (Vitis vinifera. L.). Bull. Soc. bot. Fr., Lettres bot. 135 : 251-261.

Barbier, M. and R. Bessis. 1990. Isolation and culture of grape vine cv. Chardonnay leaf protoplasts. Euphytica $47: 39-44$

Clog, E., P. Bass, and B. Walter. 1990. Plant regenera. tion by organogenesis in Vitis rootstock species. Plant Cell Reports 8: 726-728.

Gamborg, O. L., R. A. Miller and K. Ojima. 1968. Nutrient requirements of suspension culture of soybean root cells. Exp. Cell Res. 50:569-574.

Hirabayashi, T. 1985. Somatic embryogenesis from leaf tissues of grape. p. 75-82. In : Colloque Amélioration de la vigne et culture in vitro. MoëtHennessy, Paris.

Katsirdakis, K. C. and K. A. Roubelakis-Angelakis. 1992. Modified culture conditions for increased viability and cell wall synthesis in grape (Vitis vinifera L. cv. Sultanina) leaf protoplasts. Plant Cell Tiss. Org. Cult. $28: 255-260$.

Lee, N. and H. Y. Wetzstein. 1988. Protoplast isolation and callus production from leaves of tissue-culture Vitis spp. Plant Cell Reports 7 : 531-534.

Marchenko, A. O. 1991. Induction of embryogenesis in primary calluses from grape stem and leaves. Soviet Plant Physiol. $38: 428-436$.

Marino, G. 1990. Isolation and culture of mesophyll protoplasts of grape (Vitis vinifera L.), cv. Trebbiano di Romagna. Acta Hortic. 280 : 281-284.

Martinelli, L., P. Bragagna, V. Poletti and A. Scienza. 1993. Somatic embryogenesis from leaf- and petiole-derived callus of Vitis rupestris. Plant Cell Reports $12: 207-210$.

Matsuta, N. and T. Hirabayashi. 1989. Embryogenic cell lines from somatic embryos of grape (Vitis vinifera L.). Plant Cell Reports $7: 684-687$.

Matsuta, N. 1992. Effect of auxin on somatic embryogenesis from leaf callus in grape (Vitis spp.). Japan. J. Breed. $42: 879-883$.

Mii, M., Y. M. Zou, T. Sugiyama, S. Yanagihara and M. Iizuka. 1991. High-frequency callus formation from protoplasts of Vitis labruscana Bailey and $V$ itis thunbergii Sieb. et Zucc. by embedding in gellan gum. Scientia Hortic. $46: 253-260$.

Murashige, T. and F. Skoog. 1962. A revised medium for rapid growth and bioassay with tobacco tissue cultures. Physiol. Plant. 15 : 473-497.

Robacker, C. 1993. Somatic embryogenesis and plant regeneration from muscadine grape leaf explants. HortScience 28: 53-55.

Shimizu, J.-I. 1985. Cell regeneration and division of grape mesophyll protoplasts. J. Plant Physiol. 119 : 419-424.

Skene, K. G. M. 1975. Production of callus from protoplasts of cultured grape pericarp. Vitis 14 : $177-180$.

Stamp, J. A. and C. P. Meredith. 1988. Somatic embryogenesis from leaves and anthers of grapevine. Scientia Hortic. 35 : 235-250.

Theodoropoulos, P. A. and K. A. Roubelakis-Angelakis. 1990. Progress in leaf protoplast isolation and culture from virus-free axenic shoot cultures of Vitis vinifera L.. Plant Cell Tiss. Org. Cult. 20 : $15-23$.

Wright, D. C. 1985. Factors affecting isolation of protoplasts from leaves of grape (Vitis vinifera). Plant Cell Tiss. Org. Cult. $4: 95-100$. 


\title{
ブドウ葉肉プロトプラストの単離および培養に及ぼす酵素液の影響 \\ Thawansak Phosang ${ }^{1.2} \cdot$ 松田 長生 $^{1} \cdot$ 池谷祐幸 $^{1} \cdot$ 林 $^{\text {建樹 }^{1} \cdot \text { 尾形亮輔 }}{ }^{2}$ \\ 1果樹試験場 305 茨城県つくば市 \\ 2宇都宮大学農学部 321 宇都宮市峰町
}

\begin{abstract}
摘 要
ブドウのプロトプラスト培養系を確立するために， '巨峰', ‘カベルネ・ソービニヨン'の無菌個体からの 葉肉プロトプラストの単離および培餋について検討し た、いくつかの酳素液を検討した結果，プロトプラス トの収量は，0.5\%セルラーゼYC，0.2\%マセロザイ ム R-10，0.1\%ドリセラーゼを組み合わせた醳素液を 用いた場合に良い結果が得られ， 巨峰'，カカベルネ・ ソービニヨン'でそれぞれ $1.8 \times 10^{7} / \mathrm{g}$ 新鮮重, $2.4 \times$ $10^{7} / \mathrm{g}$ 新鮮重のプロトプラストが単離された。単離さ れたプロトプラストは，85\%以上の生存率を示した。

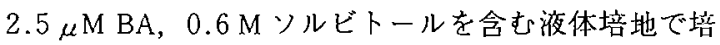
養したところ，培盖後 5 日目には上記の䣼素液を用い て単離したプロトプラストの約 $80 \%$ で細胞壁の再生 が観察され，一部のプロトプラストは分裂を開始した。 細胞分裂は，5\%セルラーゼ YC，0.2\%マセロザイム R-10，0.1\%ドリセラーゼ，0.01\%ペクトリアーゼ Y-23を組み合わせた酤菜液で単離したプロトプラス 卜に拉いて認められ，巨峰では $12 \%$ 分裂頻度であ った。しかし，‘カベルネ・ソービニヨン'では分裂頻 度が低く，1.4\%しか分裂しなかった。
\end{abstract} また，プロトプラストを B 5 基本培地に $5 \mu \mathrm{M} 2,4$-D， 